\title{
PENGETAHUAN IBU TENTANG KARTU MENUJU SEHAT (KMS) MEMPENGARUHI PERTUMBUHAN BALITA
}

\author{
Arum Meiranny ${ }^{1}$ \\ ${ }^{1}$ Universitas Islam Sultan Agung \\ E-mail:_ameiranny@gmail.com
}

\begin{abstract}
ABSTRAK
Ibu yang memiliki Balita kurang memperhatikan KMS untuk memantau pertumbuhan Balita, sehingga pertumbuhan anak kurang optimal. Penelitian ini bertujuan untuk mengetahui hubungan tingkat pengetahuan ibu tentang KMS dengan pertumbuhan Balita. Jenis penelitian dalam penelitian ini adalah analitis, dengan pendekatan cross sectional. Populasi yang digunakan adalah ibu Balita di Wilayah RW V Kelurahan Kalipancur Kecamatan Ngaliyan Kota Semarang, dengan jumlah sampel 47 orang. Tehnik sampling yang digunakan adalah quota sampling. Uji analisis yang digunakan adalah analisis univariat dan analisis bivariat menggunakan Chi Square. Hasil penelitian menunjukkan masih banyak ibu Balita yang kurang mengetahui tentang KMS (63,8 \%). Kurangnya pengetahuan tersebut mengakibatkan banyaknya Balita yang tidak mengalami kenaikan berat badan $(80,9 \%)$. Analisis Chi Square menunjukkan bahwa ada hubungan tingkat pengetahuan ibu tentang KMS dengan pertumbuhan Balita ( $\mathrm{p}=0,007)$, sehingga dapat disimpulkan bahwa ada hubungan tingkat pengetahuan ibu tentang KMS dan pertumbuhan Balita di Wilayah RW V Kelurahan Kalipancur Kecamatan Ngaliyan Kota Semarang. Saran bagi ibu agar lebih memperhatikan kualitas pertumbuhan Balitanya, bagi Posyandu, dapat memaksimalkan pelaksanaan sistem 5 meja, dan bagi petugas kesehatan dapat memberi motivasi bagi kader untuk dapat memberikan informasi tentang KMS dan mengatur jadwal pelaksanaan Posyandu, sehingga memungkinkan para ibu untuk dapat mengantar Balitanya ke Posyandu.
\end{abstract}

Kata Kunci : Pengetahuan; Kartu Menuju Sehat (KMS); Pertumbuhan Balita

\section{MOTHER'S KNOWLEDGE ABOUT ROAD TO HEALTH CHART (RHC) INFLUENCE THE GROWTH OF CHILDREN UNDER FIVE AGES}

\begin{abstract}
Mothers who have child under five ages giving less attention to Road to Health Chart (RHC) as the controlling media of children growth under five. This research was done with the purpose to know the corelation beetwen mother's level of knowledge about RHC with the growth of children under five ages. This research was conducted by analythical research with cross sectional approach. Population used mother of children under five ages at administrative unit V of the Kalipancur Village Ngaliyan Subdistrict Semarang City with 47 samples. Sampling technique used by this research was quota sampling. Analysis test using by univariate and bivariate analysis which uses Chi Square. The result of this research indicated that there were still many mother of children under five ages which unknown concerning RHC $(63,8 \%)$. The lack knowledge regarding such matter caused many children under five ages shall not having normal with growth $(80,9 \%)$. Chi Square analysis shows that there was a corelation between mother's level of knowledge about RHC with the growth of child under five ages ( $p=0,007)$, so it could be concluded that there was a corelation between mother's level of knowledge about RHC with the growth of child under five ages. Suggestion particularly to mother of children under five ages was give greater concern to the growth quality of their under five children, to the integral health post that it could maximized the implementation of five tables system, and for the health service personal to giving a motivation to the cadres, so that they could shale appropriate information concerning RHC and arrange their schedule for appliying or visiting the integral health post and enable mother to carry their children to that place her self.
\end{abstract}

Keywords: Knowledge, Road To Health Chart (Rhc), The Growth Of Children Under Five Ages. 


\section{Pendahuluan}

Balita adalah seluruh laki-laki dan perempuan yang berumur 1-5 tahun. Secara individu, pada usia Balita terjadi proses pertumbuhan yang telah berlangsung stabil. Untuk mendukung stabilitas kesehatan pada Balita dapat diupayakan antara lain dengan asupan gizi, lingkungan pengasuhan yang baik, lingkungan yang aman dan nyaman, dan lain-lain. Dari dukungan tersebut, diharapkan pertumbuhan Balita akan maksimal.

Masa Balita merupakan masa yang memerlukan perhatian khusus, karena pada masa ini terdapat pertumbuhan dan perkembangan yang sangat pesat. Masa ini juga termasuk masa yang rawan terhadap penyakit, sehingga peran keluarga, terutama ibu sangat dominan. Untuk memonitor pertumbuhan Balita secara cermat, maka dapat digunakan Kartu Menuju Sehat (KMS) (Arisman, 2007).

Semakin meningkatnya taraf pendidikan dan keterampilan wanita Indonesia, serta berkembangnya perekonomian di negara kita, maka semakin terbuka lapangan kerja untuk wanita di berbagai bidang, dan semakin banyak pula ibu yang bekerja di luar rumah. Akibatnya semakin banyak ibu yang kurang memperhatikan kebutuhan anaknya, termasuk KMS yang dapat digunakan untuk memantau pertumbuhan anaknya. Kurangnya pengetahuan orang tua tentang KMS, khususnya para ibu, akan berakibat kurang baik bagi pertumbuhan anak dan mengakibatkan pertumbuhan anak kurang optimal (Pristiani, 2012).

Berdasarkan data yang peneliti dapatkan di Wilayah RW V Kelurahan Kalipancur Kecamatan Ngaliyan Kota Semarang pada Bulan Februari 2015, terdapat 95 ibu yang memiliki Balita, dan 87,7 \% diantaranya adalah wanita pekerja, baik di instansi pemerintah maupun swasta. Para wanita pekerja ini memiliki kecenderungan untuk menyerahkan tanggung jawab akan keadaan dan perkembangan kesehatan Balita kepada para pramusiwi. Saat melaksanakan studi pendahuluan, peneliti melakukan observasi dan wawancara kepada 47 ibu Balita, dan diantaranya hanya $34 \%$ ibu yang mengetahui KMS secara baik dan benar.

\section{Tinjauan Teoritis}

Pertumbuhan adalah bertambahnya ukuran fisik dan struktur tubuh dalam arti sebagian atau seluruhnya karena adanya multiplikasi (bertambah banyak) sel-sel tubuh dan juga karena bertambah besarnya sel (Soetjiningsih, 2014). Perubahan ukuran juga terjadi pada proses pertumbuhan. Perubahan ini terlihat secara jelas pada pertumbuhan fisik yang dengan bertambahnya umur anak terjadi pula penambahan berat badan, tinggi badan, lingkaran kepala dan lain-lain. 
Berat badan merupakan ukuran antropometrik yang cukup penting. Di Indonesia, salah satu cara pemantauan berat badan menggunakan KMS. KMS adalah alat untuk mencatat dan mengamati perkembangan kesehatan anak yang mudah dilakukan oleh para ibu. Pertumbuhan Balita dari KMS dapat diketahui apabila setiap bulan ditimbang, hasil penimbangan dicatat di KMS, dan dihubungkan antara titik berat badan pada KMS dari hasil penimbangan bulan lalu dan hasil penimbangan bulan ini. Rangkaian garis-garis pertumbuhan anak tersebut membentuk grafik pertumbuhan anak. Pada Balita yang sehat, berat badannya akan selalu naik, mengikuti pita pertumbuhan sesuai dengan umurnya (Ika, 2017).

Berdasarkan hubungan 2 titik di grafik KMS, terdapat 5 kemungkinan pertumbuhan, yaitu : Catch Up, Normal Growth, Growth Faltering, Flat Growth, dan Loss of Growth. Dari kelima kemungkinan pertumbuhan tersebut, yang dikatakan naik $(\mathrm{N})$ adalah 1 atau 2 . Sedangkan dikatakan tidak naik adalah poin 3, 4, dan 5 (Depkes, 2009).

Seseorang yang mempunyai pengetahuan dan pendidikan yang tinggi akan lebih memperhatikan pertumbuhan dan perkembangan anaknya. Pengetahuan merupakan hasil dari tahu setelah seseorang melakukan penginderaan terhadap suatu objek tertentu melalui indera penglihatan, pendengaran, penciuman, perasaan, dan perabaan. Pengetahuan seseorang diperoleh dari berbagai macam sumber (Notoadmojo, 2010). Pengetahuan seseorang dinyatakan baik bila > 80\% (skor $9-10$ ), cukup bila 60-80\% (skor 6-8), dan kurang bila < $60 \%$ (skor $1-5)$.

\section{Metode Penelitian}

Metode penelitian ini menggunakan metode pendekatan cross sectional, yaitu penelitian untuk mempelajari dinamika korelasi antara faktor-faktor resiko dengan efek, dengan cara pendekatan, observasi, atau pengumpulan data sekaligus pada suatu saat.

Subjek penelitian ini adalah seluruh ibu yang memiliki Balita, yang bertempat tinggal di Wilayah RW V Kelurahan Kalipancur Kecamatan Ngaliyan Kota Semarang pada Bulan Mei 2015 yang menyatakan setuju untuk mengikuti penelitian dengan menandatangani lembar persetujuan setelah penjelasan (PSP). Jumlah populasi sebanyak 86 orang, dengan kriteria inklusi yaitu Semua ibu yang memiliki Balita, yang bertempat tinggal di Wilayah RW V Kelurahan Kalipancur Kecamatan Ngaliyan Kota Semarang, ibu bersedia menjadi responden yang dibuktikan dengan tanda persetujuan, Balita memiliki KMS, Balita ditimbang selama tiga bulan berturut-turut. Teknik pengambilan sampel yang digunakan adalah quota sampling karena dilakukan pembatasan atau jatah, sampai jumlah quota yang sudah ditetapkan dapat 
terpenuhi. Dalam penelitian ini jumlah sampel yang digunakan sejumlah 47 dengan taraf kesalahan $10 \%$.

Instrumen yang digunakan untuk mengukur variabel tingkat pengetahuan ibu tentang KMS adalah kuesioner. Sedangkan untuk menilai pertumbuhan Balita digunakan KMS Balita. Analisis Univariat ditampilkan dalam bentuk tabel distribusi frekuensi, sedangkan analisis Bivariat dilakukan dengan Chi-Square

Penelitian ini berupaya memegang teguh sikap ilmiah dan etika dalam penelitian. Peneliti berusaha meminimalkan kerugian yang mungkin timbul dan memaksimalkan penelitian. Penelitian ini dilakukan di Wilayah RW V Kelurahan Kalipancur Kecamatan Ngaliyan Kota Semarang pada Bulan April-Agustus 2015.

\section{Hasil Penelitian}

A. Karakteristik ibu

1. Umur

Tabel 1. Distribusi Umur Ibu

\begin{tabular}{ccc}
\hline Umur & Frekuensi (n) & Persentase (\%) \\
\hline $20-35$ & 47 & 100 \\
\hline Jumlah & 47 & 100 \\
\hline
\end{tabular}

Berdasarkan tabel tersebut, dapat dilihat bahwa seluruh ibu berada dalam usia reproduksi, yaitu sebanyak 47 orang (100\%).

2. Pendidikan

Tabel 2. Distribusi Pendidikan Ibu

\begin{tabular}{ccc}
\hline Pendidikan & Frekuensi $(\mathrm{n})$ & Persentase $(\%)$ \\
\hline SD & 3 & 6,4 \\
SMP & 8 & 17,0 \\
SMA & 26 & 55,3 \\
PT & 10 & 21,3 \\
\hline Jumlah & 47 & 100 \\
\hline
\end{tabular}

Berdasarkan tabel tersebut, pendidikan ibu paling banyak adalah SMA, yaitu sebanyak 26 orang $(55,3 \%)$.

3. Pekerjaan

Tabel 3. Distribusi Pekerjaan Ibu

\begin{tabular}{ccc}
\hline Pekerjaan & Frekuensi $(\mathrm{n})$ & Persentase $(\%)$ \\
\hline PNS/TNI/POLRI & 5 & 10,6 \\
Karyawan swasta & 28 & 59,6 \\
Wiraswasta & 7 & 14,9 \\
IRT & 7 & 14,9 \\
\hline Jumlah & 47 & 100 \\
\hline
\end{tabular}


Berdasarkan tabel tersebut, pekerjaan ibu yang paling banyak adalah karyawan swasta, yaitu sebanyak 28 orang $(59,6 \%)$.

B. Karakteristik Balita

1. Jenis kelamin Balita

Tabel 4. Jenis Kelamin Balita

\begin{tabular}{ccc}
\hline $\begin{array}{c}\text { Jenis } \\
\text { Kelamin }\end{array}$ & Frekuensi (n) & Persentase (\%) \\
\hline Laki-laki & 18 & 38,3 \\
Perempuan & 29 & 61,7 \\
\hline Jumlah & 47 & 100 \\
\hline
\end{tabular}

Berdasarkan tabel tersebut, jenis kelamin Balita dominan perempuan $(61,7 \%)$.

2. Pengantar Balita ke Posyandu

Tabel 5. Pengantar Balita ke Posyandu

\begin{tabular}{ccc}
\hline Pengantar Balita & Frekuensi (n) & Persentase $(\%)$ \\
\hline Ibu & 9 & 19,1 \\
Saudara & 8 & 17,0 \\
Tetangga & 2 & 4,3 \\
Pramusiwi & 28 & 59,6 \\
\hline Jumlah & 47 & 100 \\
\hline
\end{tabular}

Berdasarkan tabel tersebut, pengantar Balita ke Posyandu didominasi pramusiwi $(59,6 \%)$ yang notabene tingkat pendidikan dan pengetahuannya masih kurang.

C. Tingkat Pengetahuan Ibu tentang KMS

Tabel 6. Tingkat Pengetahuan Ibu tentang KMS

\begin{tabular}{ccc}
\hline Tingkat Pengetahuan Ibu & Frekuensi (n) & Persentase (\%) \\
\hline Kurang & 30 & 63,8 \\
Baik & 17 & 36,2 \\
\hline Jumlah & 47 & 100 \\
\hline
\end{tabular}

Berdasarkan tabel tersebut, dapat diketahui bahwa tingkat pengetahuan ibu tentang KMS cenderung kurang, yaitu sebanyak 30 orang $(63,8 \%)$.

D. Pertumbuhan Balita

Tabel 7. Gambaran Pertumbuhan Balita

\begin{tabular}{ccc}
\hline Pertumbuhan Balita & Frekuensi (n) & Persentase $(\%)$ \\
\hline Tidak naik & 38 & 80,9 \\
Naik & 9 & 19,1 \\
\hline Jumlah & 47 & 100 \\
\hline
\end{tabular}

Berdasarkan tabel tersebut, dapat diketahui bahwa distribusi frekuensi tentang variabel penelitian terlihat bahwa Balita yang berat badannya tidak naik $(80,9 \%)$ jauh lebih banyak dibandingkan Balita yang berat badannya naik $(19,1 \%)$. 
E. Hubungan Tingkat Pengetahuan Ibu tentang KMS dan Pertumbuhan Balita

Tabel 8. Hubungan Tingkat Pengetahuan Ibu tentang KMS dan Pertumbuhan Balita

\begin{tabular}{lccccccc}
\hline \multirow{2}{*}{$\begin{array}{l}\text { Tingkat } \\
\text { pertumbuhan Balita }\end{array}$} & \multicolumn{2}{c}{ Tidak naik } & \multicolumn{2}{c}{ Naik } & \multicolumn{2}{c}{ Total } & $p$ value \\
\cline { 2 - 7 } pengetahuan ibu & $\mathrm{n}$ & $\%$ & $\mathrm{n}$ & $\%$ & $\mathrm{~N}$ & $\%$ & 0,007 \\
\hline Kurang & 28 & 93,3 & 2 & 6,7 & 30 & 100 & \\
Baik & 10 & 58,8 & 7 & 41,2 & 17 & 100 & \\
\hline
\end{tabular}

Berdasarkan tabel tersebut dapat diketahui bahwa dari sejumlah ibu yang tingkat pengetahuannya tentang KMS kurang, sebagian besar Balitanya tidak mengalami kenaikan berat badan, yaitu sebesar 93,3\%, dan yang mengalami kenaikan berat badan sebesar 6,7\%. Sedangkan ibu yang mengetahui KMS dengan baik, dengan Balitanya yang tidak mengalami kenaikan berat badan sebesar 58,8\%, dan yang mengalami kenaikan berat badan sebesar 41,2\%. $P$ value diperoleh 0,007 .

\section{Pembahasan}

Lokasi penelitian adalah Wilayah RW V Kelurahan Kalipancur Kecamatan Ngaliyan Kota Semarang. Wilayah ini termasuk Wilayah kerja Puskesmas Purwoyoso. Posyandu di RW $\mathrm{V}$ dapat dikatakan cukup aktif setiap bulan, sistim pelaksanaanya juga telah berjalan cukup baik dengan sistim 5 meja, walaupun belum begitu maksimal, seperti banyak Balita yang belum mendaftar, tapi sudah dilakukan penimbangan. Hal tersebut terjadi karena banyak pengantar Balita yang tidak mau menunggu terlalu lama di Posyandu, sehingga suasana di Posyandu menjadi kurang tertib dan kurang kondusif. Posyandu dilakukan setiap Hari Selasa minggu ketiga, sehingga banyak ibu bekerja yang tidak dapat mengantarkan Balitanya ke Posyandu untuk dilakukan penimbangan.

Berdasarkan tabel 1 tentang umur ibu, seluruh ibu memiliki rentang umur 20-35 tahun, sehingga seluruh ibu berada dalam usia reproduktif. Pada umur tersebut, seseorang telah memiliki cara berpikir yang cukup matang . namun, di sisi lain, mereka memiliki keinginan yang cukup kuat untuk melakukan aktivitas yang dapat mengurangi peran dan tanggung jawabnya sebagai ibu. Faktor umur sangat berpengaruh pada perilaku dan pengetahuan seseorang. Hal tersebut didukung oleh pendapat Notoadmodjo, bahwa umur merupakan salah satu faktor terbentuknya perilaku seseorang. Semakin lanjut umur seseorang, maka pada umumnya akan meningkat cara berpikir orang tersebut (Notoadmojo, 2010). 
Tingkat pendidikan ibu yang paling dominan adalah SMA. Pengetahuan seseorang tidak dapat terlepas dari pendidikannya. Pada umumnya, semakin tinggi pendidikan formal yang diterima seseorang, maka responnya akan lebih rasional terhadap informasi yang diterimanya ${ }^{8}$. Sesuai dengan pendapat Soetjiningsih, bahwa pendidikan orang tua merupakan salah satu faktor yang penting dalam tumbuh kembang anak. Karena dengan pendidikan yang baik, maka orang tua dapat menerima segala informasi dari luar terutama tentang cara pengasuhan anak yang baik, bagaimana menjaga kesehatan anak, pendidikannya dan sebagainya (Sotjiningsih, 2014). Tingkat pendidikan para pengasuh Balita cenderung rendah, sehingga krang mampu memahami dengan baik kualitas pertumbuhan Balita yang diasuhnya.

Berdasarkan data dari tabel 3, jenis pekerjaan ibu yang paling banyak adalah karyawan swasta. Jenis pekerjaan ini sangat menyita waktu, karena mayoritas mereka berangkat pagi dan pulang petang, sehingga kesempatan untuk memperhatikan pertumbuhan Balita sangat sedikit.

Berdasarkan tabel 4, jenis kelamin Balita paling banyak adalah wanita, yaitu sebanyak 29 Balita. Salah satu faktor yang mempengaruhi tumbuh kembang adalah jenis kelamin. Pertumbuhan wanita lebih cepat dibanding laki-laki. Namun, setelah melewati masa pubertas, pertumbuhan laki-laki akan lebih cepat dibanding wanita.

Hasil penelitian menunjukkan bahwa pada saat Balita hadir di Posyandu, mayoritas diantar oleh pramusiwi. Hal tersebut dapat dilihat dari tabel 5. Tingkat pendidikan dan pengetahuan pramusiwi cenderung rendah, sehingga apabila diberi penyuluhan, daya serap pemikirannya kurang maksimal. Bahkan, setelah mendapatkan penyuluhan tentang pertumbuhan Balita, mereka tidak menyampaikan kepada ibu Balita. Hal inilah yang menyebabkan terputusnya mata rantai informasi tentang pertumbuhan Balita.

Kualitas pengasuhan anak bisa menjadi faktor penyebab yang dominan. Pola asuh Balita yang banyak dijumpai saat ini, tidak jarang Balita berada dibawah asuhan orang-orang yang tidak semestinya, seperti kakek atau nenek, saudara, bahkan pramusiwi yang kurang memahami dan mengetahui hal-hal yang berkaitan dengan penyediaan makanan karena orang tua sibuk bekerja. Padahal makanan merupakan salah satu faktor yang terpenting bagi pertumbuhan Balita (Iwan, 2011).

Berdasarkan tabel 6, dapat dilihat bahwa pengetahuan ibu tentang KMS cenderung kurang $(63,8 \%)$. Hal tersebut terjadi karena kurangnya informasi tentang KMS dan sebagian besar adalah wanita karir yang cenderung menyerahkan segala urusan Balitanya kepada pramusiwi. Selain itu, mereka kurang mempunyai motivasi yang kuat untuk berperan aktif dalam pertumbuhan Balitanya. Sebanyak 20 pertanyaan yang diajukan, pertanyaan yang paling sedikit terjawab oleh ibu Balita adalah poin tentang grafik KMS. 
Tabel 7 menunjukkan bahwa sebagian besar Balita tidak mengalami kenaikan berat badan. Asupan makanan Balita dipengaruhi oleh lingkungan keluarga, terutama ibu, karena ibu memiliki peranan yang sangat penting bagi pertumbuhan Balita (Soetjiningsih, 2014). Namun, pada penelitian ini, sebagian besar ibu adalah wanita karir, yang mengakibatkan urusan makanan diserahkan pada pramusiwi, dengan segala konsekuensinya terhadap kuantitas, kualitas, serta kebiasanaan makan.

Asupan gizi yang tepat, akan berpengaruh terhadap perubahan berat badan. Berat badan yang dipantau melalui KMS, dikategorikan melalui grafik. Grafik tersebut disesuaikan antara umur dan berat badan Balita. Grafik tersebut dapat dilihat setelah ketiga titik berat badan dihubungkan. Dengan membaca garis perkembangan berat badan anak dari bulan ke bulan pada KMS, seseorang dapat menilai dan berbuat sesuatu (Sotjiningsih, 2014).

Pada tabel 8, dapat dilihat bahwa Berdasarkan dari sejumlah ibu yang tingkat pengetahuannya tentang KMS kurang, sebagian besar Balitanya tidak mengalami kenaikan berat badan, yaitu sebesar 93,3\%, dan yang mengalami kenaikan berat badan sebesar 6,7\%. Sedangkan ibu yang mengetahui KMS dengan baik, dengan Balitanya yang tidak mengalami kenaikan berat badan sebesar 58,8\%, dan yang mengalami kenaikan berat badan sebesar 41,2\% . Pertumbuhan Balita dipengaruhimoleh beberapa faktor, faktor-faktor tersebut merupakan rangkaian yang tidak dapat dipisahkan, saling terkait antara satu dan lainnya. Diantara beberapa faktor yang mempengaruhi pertumbuhan Balita, faktor pengetahuan ibu tentang KMS memiliki peran yang cukup dominan. Hal tersebut dibuktikan dari penelitian ini, dengan melihat hasil $P$ value $=0,007$.

\section{Kesimpulan}

Ada hubungan antara tingkat pengetahuan ibu tentang KMS dengan pertumbuhan Balita.

\section{Saran}

Saran bagi ibu agar lebih memperhatikan kualitas pertumbuhan Balitanya, bagi Posyandu, dapat memaksimalkan pelaksanaan sistem 5 meja, dan bagi petugas kesehatan dapat memberi motivasi bagi kader untuk dapat memberikan informasi tentang KMS dan mengatur jadwal pelaksanaan Posyandu, sehingga memungkinkan para ibu untuk dapat mengantar Balitanya ke Posyandu. 


\section{Daftar Pustaka}

Arisman (2007). Gizi Dalam Daur Kehidupan. Jakarta: Penerbit Buku Kedokteran.

IkaTristantia, Risnawatia I (2017). Motivasi Kader Dan Kelengkapan Pengisian Kartu Menuju Sehat Balita Di Kabupaten Kudus. Indonesia Jurnal Kebidanan.

Iwan S. Pengasuhan Anak dalam Keluarga : the Next Lost Generation. www.poltekkesmalang.ac.id; 2008 [diunduh 2 Juli 2009].

Notoadmodjo S (2010). Ilmu Pendidikan dan Perilaku Kesehatan. Jakarta: Rineka Cipta.

Pristiani E, Junaid, Paridah (2016). Hubungan Pengetahuan, Sikap, Dan Status Pekerjaan Ibu Balita Dengan Frekuensi Penimbangan Balita Ke Posyandu Di Wilayah Kerja Puskesmas Pamandati Kabupaten Konawe Selatan. Fakultas Kesehatan Masyarakat Universitas Halu Oleo. unsubmitted.

RI D (2009). Pedoman Penggunaan Kartu Menuju Sehat (KMS) Balita. Jakarta: Departemen Kesehatan RI.

Soetjiningsih (2014). Tumbuh Kembang Anak. Jakarta: Sagung Seto. 